\title{
APPLICATION OF ISCHEMIC COMPRESSION TECHNIQUE AND MYOFASCIAL RELEASE TECHNIQUE IN LUMBAL SPONDYLOSIS PATIENTS IN RATULANGI MAKASSAR MEDICAL CENTER
}

\author{
Suharto, Suriani \\ Department of Physiotherapy Health Polytechnic Ministry of Health Makassar \\ E-mail correspondence: Suhartoft11@gmail.com
}

\begin{abstract}
Lumbar spondylosis is a condition of lower back pain caused by disc degeneration and facet joint which is characterized by osteophyte growth in the vertebral body precisely at the inferior and superior corpus edges, causing problems of pain, spasm, and impaired lumbar flexibility. The purpose of this study was to determine the difference in effect between the Ichemic compression technique (ICT) and Myofascial Release Technique (MRT) on the improvement of Lumbar Flexibility in patients with lumbar spondylosis, which was carried out at the Physiotherapy Clinic of TK II Pelamonia Hospital Makassar. The number of research subjects obtained as many as 20 people who meet the research criteria Then randomized into 2 groups: the treatment group I with ICT as many as 10 people and the treatment group II as many as 10 people with MRT. The research results show that the administration of Ichemic Compression Technique can increase lumbar flexibility with a mean difference 1,250. Whereas MRT administration can increase lumbar flexibility with a mean difference of 1,950. Wilcoxon test results of the treatment group I on the flexibility component obtained $p$ value $=0.004$ ( $p$ $<0.05)$ while the treatment group II on the lumbar flexibility component obtained $p$ value $=0.004(p<0.05)$ which means that the provision of ICT with MRT can produce significant effect on increasing lumbar flexibility in patients with lumbar spondylosis. Mann Whitney test results on the lumbar flexibility component for treatment groups I and II $p$ value $=0.035$ $(p<0.05)$. If seen from the mean values above, it can be concluded that the administration of Myofascial Release Technique (MRT) can result in a greater increase in lumbar flexibility compared to the Intermitten compression technique.
\end{abstract}

Keywords: Ichemic compression technique., Lumbar flexibility, Myofascial Release Technique, Lumbar Spondylosis

\section{ABSTRAK}

Spondylosis lumbal merupakan kondisi nyeri pinggang bawah yang disebabkan oleh degenerasi diskus dan facet joint yang ditandai dengan pertumbuhan osteofit pada corpus vertebra tepatnya pada tepi inferior dan superior corpus sehingga menimbulkan problem nyeri, spasme, dan gangguan fleksibilitas lumbal. Tujuan penelitian untuk mengetahui beda pengaruh antara Ichemic compression technique (ICT) dengan Myofascial Release Technique (MRT) terhadap Peningkatan Fleksibilitas Lumbal pada penderita spondylosis lumbal, yang dilaksanakan di poliklinikFisioterapi RS TK II Pelamonia Makassar. Jumlah subjek penelitian diperoleh sebanyak 20 orang yang memenuhi kriteria penelitian Kemudian dirandomisasi kedalam 2 kelompok yaitu kelompok perlakuan I dengan ICT sebanyak 10 orang dan kelompok perlakuan II sebanyak 10 orang dengan MRT.Hasil penelitian menunjukkan bahwa pemberian Ichemic Compression Technique dapat meningkatkan fleksibilitas lumbal dengan rerata selisih 1,250. Sedangkan pemberian MRT dapat meningkatkan fleksibilitas lumbal dengan rerata selisih 1,950. Hasil uji Wilcoxon kelompok perlakuan I pada komponen fleksibilitas diperoleh nilai $p=0,004(p<0,05)$ sedangkan kelompok perlakuan II pada komponen fleksibilitas lumbal diperoleh nilai $p=0,004(p<0,05)$ yang berarti bahwa pemberian ICT dengan MRT dapat menghasilkan pengaruh yang bermakna terhadap peningkatan fleksibilitas lumbal pada penderita spondylosis lumbal. Hasil uji Mann Whitney pada komponen fleksibilitas lumbal untuk kelompok perlakuan I dan II nilai $p=0,035(p<0,05)$. Jika dilihat dari nilai rerata diatas menunjukkan bahwa pemberian Myofascial Release Technique (MRT)dapat menghasilkan peningkatan fleksibilitas lumbal yang lebih besar dibandingkan dengan Intermitten compression technique.

Kata Kunci : Ichemic compression technique., Fleksibilitas lumbal, Myofascial Release Technique,, Spondylosis Lumbal.

\section{PENDAHULUAN}

Spondylosis lumbal merupakan penyakit degeneratif pada corpus vertebra atau diskus intervertebralis. Kondisi ini lebih banyak menyerang pada wanita. Faktor utama yang bertanggung jawab terhadap perkembangan spondylosis lumbal adalah usia, obesitas, duduk dalam waktu yang lama dan kebiasaan postur yang jelek. Pada faktor usia menunjukkan bahwa kondisi ini banyak dialami oleh orang yang berusia 40 tahun keatas. Faktor obesitas juga berperan dalam menyebabkan perkembangan spondylosis lumbal (Jupiter Infomedia, 2009).

Perubahan degeneratif pada tulang belakang ditemukan mulai pada awal usia 15 tahun, tetapi gejala hanya terjadi pada individu yang jauh lebih tua. Dalam hasil penelitian di Amerika Serikat, osteoarthritis sendi facet dari hasil CT scan ditemukan $36 \%$ pada usia 45 tahun, $67 \%$ usia $45-64$ tahun, dan $89 \%$ pada usia lebih dari 65 tahun. Selanjutnya sebuah studi 
epidemiologi besar di Jepang melaporkan prevalensi radiografi lumbar spondylosis sebagai $75,8 \%$ pada orang yang berusia diatas 60 tahun (Wang Runsheng \& Ward Michael M, 2015).

Perubahan degeneratif pada korpus vertebra akibat penyakit degeneratif diskus lumbalis dan osteosrthritis facies artikularis umumnya mengacu pada spondylosis lumbalis dan khas terjadi pada usia lanjut. Gejala yang paling sering adalah nyeri pinggang bawah yang bersifat kronis yang kadang nyeri menyebar ke pantat. Kadang disertai kekakuan di pagi hari, nyeri yang tergantung pada posisi, dan kesulitan tidur mungkin terjadi (Lawry George V, 2016).

Kondisi nyeri pinggang yang sangat berkaitan dengan usia adalah spondylosis lumbal. Menurut Kelly Redden (2009), nyeri pinggang dibagi atas 2 bagian yaitu mekanikal nyeri pinggang dan nonmekanikal nyeri pinggang dimana spondylosis lumbal merupakan salah satu kondisi nyeri pinggang yang tergolong mekanikal nyeri pinggang. Spondylosis lumbal menduduki peringkat kedua dengan persentase $10 \%$ dari mekanikal nyeri pinggang sedangkan lumbar strain/sprain memiliki persentase terbanyak yaitu $70 \%$ dari mekanikal nyeri pinggang.

Gangguan yang terjadi akibat nyeri pinggang bawah adanya nyeri tekan pada regio lumbal, spasme otot-otot pinggang, keterbatasan gerak pingang dan penurunan kekuatan otot pinggang dan ekstremitas inferior, sehingga dapat menimbulkan keterbatasan fungsi yaitu gangguan saat bangun dari keadaan duduk, saat membungkuk, saat duduk atau berdiri lama dan berjalan sehingga dapat mempengaruhi produktivitas kerja seseorang.

Nyeri pinggang merupakan problem kesehatan dan sosio-ekonomi yang besar di negara Eropa. Sepanjang hidup prevalensinya telah diperkirakan antara 59\% - 90\%. Dalam 1 tahun telah dilaporkan bahwa insiden nyeri pinggang dialami sekitar 5\% dari populasi (Navid, 2009).

Menurut Anthony $\mathrm{H}$. Wheeler (2007), sekitar $80 \%$ penduduk Amerika mengalami nyeri pinggang sepanjang hidupnya. Diperkirakan sekitar $15-20 \%$ berkembang nyeri menjalar, dan sekitar 2 $8 \%$ nyeri kronik. Setiap tahun, sekitar $3-4 \%$ dari populasi nyeri pinggang mengalami ketidakmampuan dalam aktivitas. Sedangkan insiden nyeri pinggang mencapai puncaknya pada usia pertengahan dan menurun pada usia tua.

Kasus nyeri pinggang bawah akibat spondilosis dari Maret s/d juni 2012 di RSAD Pelamonia ditemukan sebanyak 27 pasien dengan usia lebih dari 40 tahun. Umumnya mengalami nyeri, dan keterba tasan gerak fungsional sehingga mengganggu aktivitas sehari-hari pasien. Untuk mengatasi problema tersebut, berbagai modalitas fisioterapi dapat diberikan misalnya transverse friction, interferensi, William fleksion exercises dan lain-lain. Penelitian ini bertujuan mengetahui perbedaan pengaruh Intermitten Compression Technique (ICT) dengan Myofascial Release Technique (MRT) pada kondisi spondilosis Lumbal.

\section{METODE}

Penelitian ini dilaksanakan di Klinik Fisioterapi Ratulangi Medical Centre mulai Februari sampai dengan April 2015, dengan desain penelitian ini adalah two group pre test-post test design. Subjek penelitian di bagi dalam 2 kelompok, yaitu kelompok 1 (Perlakuan) diberikan Intermitten Compression Technique dan kelompok 2 (kontrol) diberikan Myofascial Release Technique. Populasi penelitian adalah pasien nyeri pinggan bawah akibat spondylosis lumbal dan sampel penelitian sebanyak 20 orang secara accidental sampling dengan kriteria inklusi penelitian, yaitu : (1) Merupakan indikasi ICT dan MRT, (2) mengalami keluhan nyeri pinggang bawah akibat spondylosis lumbal, (3) berumur 35 - $\geq 55$ tahun, dan (4) bersedia menjadi responden dalam penelitian ini. Sedangkan kriteria ekslusi adalah pasien mengalami nyeri pinggang bawah yang disertai fraktur vertebra.

\section{Jenis dan cara Pengumpulan Data}

Pengumpulan data melalui data primer dan data sekunder. Data primer diperoleh dengan cara peneliti langsung mengambil data yaitu mengukur fleksibilitas lumbal pada setiap sampel untuk mendapatkan data pre test dan post tes. Data sekunder diperoleh dengan melihat status rekam medik sampel melalui hasil foto X-Ray.

\section{Prosedur Penelitian}

a. Sampel Penelitian Jumlah sampel sebanyak 20 orang kemudian dilakukan random alokasi untuk memisahkan antara kelompok 
yang diberikan metode Intermitten Compression Technique dengan dan metode Muscle Release Technique sehingga masing-masing kelompok sebanyak 10 orang.

b. Pelaksanaan Pre-test

Pelaksanaan pretest dilakukan sebelum diberikan perlakuan yaitu pengukuran fleksibilitas lumbal dengan Modified Schober Test. Hasil yang diperoleh dicatat pada blanko pengukuran. Fleksibilitas lumbal adalah bidang gerak pada sendi lumbal yang digunakan untuk menggambarkan range of motion yang terjadi. Pengukuran dengan Modified Schober Test dilakukan dengan cara menentukan titik garis tengah antara spina iliaka posterior superior kanan-kiri pada saat berdiri tegak dan di beri tanda. Kemudian dari titik tersebut tarik garis lurus dengan menggunakan meterline ke atas sepanjang $10 \mathrm{~cm}$ dan tarik garis lurus $\mathrm{k}$ bawah sepajangan $5 \mathrm{~cm}$, masingmasing titik diberi tanda. Jadi jumlah jarak dari titik terbawah sampai teratas adalah $15 \mathrm{~cm}$ saat berdiri tegak, jarak tersebut dijadikan sebagai standar ukuran. Selanjutnya subjek penelitian di minta untuk melakukan fleksi lumbal semaksimal mungkin, dan diukur jarak antara titik terbawah sampai dengan titik teratas saat fleksi. Hasil pengukuran tersebut dikurangi $15 \mathrm{~cm}$. Fleksibilitas lumbal di katakan normal jika hasil $\geq 5,5$ $\mathrm{cm}$ pada wanita dan $\geq 7,1 \mathrm{~cm}$ pada pria, apabila hasil kurang dari nilai tersebut dapat dikategorikan fleksibilitas lumbal terbatas.

c. Pelaksanaan Penelitian

Eksperimen dalam penelitian ini adalah intervensi pada subjek penelitian sebanyak 20 orang pasien spondylosis lumbal yang dibagi dalam 2 kelompok perlakuan. Kelompok I diberikan metode Intermitten Compression Technique (ICT) dan kelompok II diberikan metode Muscle Release Technique (MRT) dengan dosis : 1 kali/hari, 3 kali seminggu dan 6 kali setiap pasien. Intermitten Compression Technique adalah suatu teknik manual terapi khusus dengan finger technique massage yang bertujuan restorasi struktural dan normalisasi fungsi myofascio articular yang mengalami disfungsi. Frekuensinya untuk satu area : 2 -3 kali dengan waktu 30 detik yang diterapkan pada otot paravertebral lumbal.

Myofascial release dilakukan dengan cara memberikan peregangan pada jaringan facia yang melekat di bagian kompleks myofascial dengan maksud untuk mengembalikan panjang optimal fasia jaringan, mengurangi rasa sakit, dan meningkatkan fungsionalitas. Miyofacial release yang diterapkan yaitu skin rolling pada otot paravertebral lumbal dengan cara menggunakan ibu jari dan jari telunjuk untuk melipat kulit dengan irama yang teratur, tujuannya yaitu untuk melonggarkan atau memisahkan lengketan yang terjadi antara kulit dengan jaringan dibawahnya.

d. Pelaksanaan Post- tes

Post test dilakukan pada 20 subjek penelitian sehari setelah perlakuan yaitu pengukuran fleksibilitas lumbal yang dicatat pada blanko pengukuran.

\section{Pengolahan Data}

Data yang diperoleh dianalisis dengan menggunakan Uji Wilcoxon dan Mann-Whitney dengan $\alpha<0,05$, karena hasil uji normalitas data diperoleh tidak berdistribusi normal. Pengolahan dan analisis data dengan menggunakan SPSS, kemudian disajikan dalam bentuk tabel dan narasi.

\section{HASIL}

\section{Karakteristik Subjek Penelitian}

Hasil penelitian pada tabel 1. dari 20 pasien nyeri pinggang bawah akibat spondilosis lumbal. Jumlah subjek laki-laki dan perempuan seimbang ( $50 \%$ vs $50 \%$ ). Sedangkan usia pasien lebih banyak pada usia $\geq 51$ tahun ( $40 \%$ ).

Tabel 2. menunjukkan nilai rerata dan standar deviasi pada kelompok perlakuan Intermitten Compression Technique dan kelompok perlakuan MRT. Pada kelompok perlakuan Intermitten Compression Technique diperoleh nilai rerata pre test sebesar $16,45_{ \pm} 0,5503 \mathrm{~cm}$ dan nilai rerata post test sebesar $17,7_{ \pm}$ $0,5375 \mathrm{~cm}$ dengan nilai rerata selisih

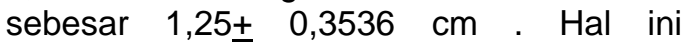
menunjukkan adanya perubahan atau peningkatan fleksibilitas lumbal setelah diberikan ICT dengan rata-rata peningkatan sebesar 1,250 cm. Pada kelompok perlakuan MRT diperoleh nilai rerata pre test sebesar $16,650_{ \pm} 1,2921 \mathrm{~cm}$ dan nilai rerata post test sebesar $18,600 \pm 1,2649 \mathrm{~cm}$ 
dengan nilai rerata selisih sebesar $1,950_{ \pm}$ 0,7619 . cm Hal ini menunjukkan adanya perubahan atau peningkatan fleksibilitas lumbal setelah diberikan Myofascial Release Technique (MRT) dengan rata-rata peningkatan sebesar $1,950 \mathrm{~cm}$.

\section{Analisis Inferensial}

Dalam analisis ini akan ditampilkan hasil analisis Uji Wilcoxon dan MannWhitney untuk komponen fleksibilitas lumbal baik pada kelompok perlakuan Intermitten Compression Technique maupun kelompok perlakuan MRT. Tabel 3, hasil Uji Wilcoxon komponen fleksibilitas lumbal kelompok perlakuan Intermitten Compression Technique diperoleh nilai $p=0,005(p<$ $0,05)$. Hal ini menunjukkan bahwa pemberian ICT dapat menghasilkan pengaruh yang bermakna terhadap peningkatan fleksibilitas lumbal pada penderita spondylosis lumbal.

Tabel 4. hasil Uji Wilcoxon pada fleksibilitas lumbal didalam kelompok perlakuan MRT diperoleh nilai $p=0,005(p$ $<0,05$ ) yang berarti Myofascial Release Tecnique (MRT) dapat menghasilkan pengaruh yang bermakna terhadap peningkatan fleksibilitas lumbal pada penderita spondylosis lumbal.

Tabel 5. Uji Mann-Whitney antara kelompok perlakuan ICT dan MRT pada komponen fleksibilitas lumbal, diperoleh nilai $p=0,035(p<0,05)$ yang berarti bahwa ada perbedaan yang bermakna antara selisih fleksibilitas lumbal kelompok perlakuan ICT dengan selisih fleksibilitas lumbal kelompok perlakuan MRT. Hal ini menunjukkan Myofascial Release Technique (MRT) dapat menghasilkan peningkatan fleksibilitas lumbal yang lebih besar secara bermakna dibandingkan dengan ICT.

\section{PEMBAHASAN}

Pada kasus spondylosis lumbal, usia merupakan faktor utama yang bertanggung jawab terhadap perkembanganya. Pada umumnya usia 40 tahun keatas sudah mengalami proses degenerasi pada tulang vertebra (Jupiter Infomedia, 2009). Namun, kondisi ini paling banyak terjadi pada usia 45 tahun.

Pada kondisi Spondylosis lumbal yang merupakan salah satu kondisi nyeri pinggang yang ditandai dengan proses degenerasi pada intervertebral joint dan apophyseal joint. Semakin bertambahnya usia maka akan terjadi penurunan secara struktural dan fungsional pada vertebra lumbal, dimana penurunan tersebut cenderung terjadi perubahan degeneratif pada sendi-sendi vertebra lumbal.

Hasil penelitian dengan pemberian ICT dapat menghasilkan peningkatan fleksibilitas lumbal secara bermakna pada penderita spondylosis lumbal, dengan rata rata peningkatan fleksibilitas lumbal sebesar 1,250. Dengan memberikan ICT pada pasien dapat memberikan efek mengurangi spasme atau tightnes otot, memecah perlengketan jaringan parut (scar tissue), serta menyusun kembali serabut otot dan ligamen kedalam pola yang lebih biofungsional.. Gerakan compression dengan tekanan sedang dapat menghasilkan efek thermal dan sedatif pada jaringan otot. Penurunan nyeri selama compression dan setelah compression disebabkan oleh modulasi impuls nosiseptive pada level medula spinalis yang dikenal dengan "gate control theory".Efek terapeutik yang dihasilkan oleh Intermitten Compression Technique (ICT) secara tidak langsung dapat menghasilkan peningkatan lingkup gerak sendi lumbal terutama fleksi lumbal sehingga terjadi peningkatan fleksibilitas lumbal. ${ }^{8}$.

Hasil penelitian dengan pemberian Myofascial Release Technique (MRT) dapat menghasilkan peningkatan fleksibilitas lumbal secara bermakna pada penderita spondylosis lumbal, dengan rata - rata peningkatan fleksibilitas lumbal sebesar 1,950. Pemberian Myofascial Release Technique menghasilkan penuru nan nyeri otot, mempercepat proses penyembuhan jaringan, meningkatkan fleksibilitas dan memperbaiki postur tubuh. (S. Chithra, et.al. 2014)

Myofascial Release Technique memfokuskan untuk mengobati titik nyeri di otot. Oleh karena itu, terapi myofascial juga dikenal sebagai terapi titik pemicu myofascial. Aplikasi Myofascial Release Technique juga memfokuskan pada kondisikondisi yang berkaitan dengan kebiasaan postural yang jelek, aktivitas spesifik atau kurangnya aktivitas, kompensasi terhadap injury sebelumnya akibat mekanikal stress yang kronik. Kondisi-kondisi tersebut sering menghasilkan kontraktur otot dan adhesion diantara lapisan-lapisan fascia. Fascia membentuk struktur pasif pada jaringan tubuh, adanya adhesion menyebabkan serabut fascia saling terikat satu sama lain 
secara disfungsional. (S. Chithra, et.al. 2014)

Metode ini berperan untuk memberikan stretch atau elongasi pada struktur otot dan fascia dengan tujuan akhir adalah mengembalikan kualitas cairan atau lubrikasi pada jaringan fascia, mobilitas jaringan fascia dan otot, dan fungsi sendi normal dapat merangsang struktur-struktur didalam jaringan otot. Efek yang dihasilkan oleh Myofascial Release Technique (MRT) terbukti pada hasil penelitian ini yang menunjukkan adanya pengaruh yang bermakna terhadap peningkatan fleksibilitas lumbal pada penderita spondylosis lumbal.

Hasil penelitian perbedaan efek antara Ichemic Compression Technique (ICT) dengan Myofascial Release Technique (MRT)terhadap Peningkatan Fleksibilitas Lumbal, menunjukkan baik Ichemic Compression Technique maupun Myofascial Release Technique (MRT) dapat menghasilkan efek pada otot erector spine lumbal sehingga dapat meningkatkan fleksibilitas lumbal. ICT pada kasus ini dapat menghasilkan stress mekanik pada struktur jaringan kolagen yang terbentuk dalam jaringan otot sehingga mencegah terbentuknya abnormal crosslink atau menyearahkan serabut kolagen yang terbentuk (James Cyriax, 1950). Sedangkan Myofascial Release Technique (MRT) menghasilkan efek stretch pada serabut otot dan fascia sehingga dapat merangsang muscle spindle serabut otot. Stimulasi pada muscle spindle dapat menginhibisi aktivitas $\delta$ motoneuraon sehingga tonus otot akan menurun dan akhirnya terjadi relaksasi otot. ( Menard D,1993)

\section{KESIMPULAN}

Kedua teknik terapi Ichemic Compression Technique dan Myofascial Release Technique dapat meningkatkan Fleksibilitas Lumbal pada pasien nyeri pinggang bawah akibat spondilosis lumbal

\section{SARAN}

Kepada fisioterapis di Ratulangi Medical Centre Makassar dan dilahan praktek agar menggunakan intervensi Ichemic Compression Technique dan Myofascial Release Technique sebagai modalitas utama pasien nyeri pinggang bawah akibat spondylosis.

\section{UCAPAN TERIMA KASIH}

Terima kasih yang dalam penulis sampaikan kepada Bapak Direktur Politeknik Kesehatan Kemenkes Makassar, Ketua Jurusan Fisioterapi, teman sejawat bapak dan ibu dosen dan semua pihak yang telah membantu penulis dalam menyelesaikan penelitian ini,semoga mendapat pahala yang berlifat ganda.

\section{DAFTAR PUSTAKA}

Ajimsha, M.S, Binsu Daniel. and S. Chithra. 2014. Effectiveness of Myofascial release in the management of chronic low back pain in nursing professionals. Journal of Bodywork \& Movement Therapies: 18, (273281). Diakses: 31 Oktober 2015 melalui http://www.sciencedirect. com/science/article/pii/ S13608592130007 4010

Anggraeni, Nanda Citra. 2013. Penerapan Myofascial Release Technique sama baik dengan Ischemic Compression Technique dalam menurunkan nyeri pada sindroma Miofascial otot Upper Trapezius. Skripsi. Denpasar: Universitas Udayana.

Ann Thomson et.al, 1991. Tidy's Physiotherapy, Twelth Edition, Butterworth Heinemann, Oxford.

Anthony H. Wheeler, 2007. Patophysiology of Chronic Back Pain, http://www. emedicine.com/article/ $\frac{1144130-}{1}$ overview, akses tanggal 30 Maret 2015.

Bruce M. Rothschild, 2009. Lumbar Spondylosis, Medscape, http://emedicine.medscape.com/ article/249036-overview, akses tanggal 28 Maret 2011.

Giring, Nofrianto, Djajakusli, Rafael, Naiem, Furqaan. 2016. Hubungan Teknik Mengangkat Beban Dengan Keluhan Nyeri Punggung Bawah $P$ ada Pekerja Angkut Beras Di Pasar Makale,

Hasanuddin_University_Repository

Jupiter Infomedia, 2009. Lumbar Spondylosis, $\quad$ http://www. indianetzone.com $/ 41 /$ treatment lumbar spondylosis.htm, akses tanggal 12 Desember 2016. 
Kelly Redden, 2009. Piriformis Syndrome: the other great imitator, Resident Grand Rounds.

Mahadewa, G.B.T dan Maliawan, S. 2009. Diagnosis dan Tatalaksana Kegawat Daruratan Tulang Belakang. Jakarta: Sagung Seto.

Muttaqin, A. 2012. Buku saku Gangguan Muskuloskeletal Aplikasi Pada Praktik Klinik Keperawatan. Jakarta: EGC.

Menard D.1993. Neuromuscular Consideration. In : Lewis CB, Knortz
KA, editors. Orthopedic Assesment and Treatment of the Geriatric Patient. St. Louis : Mosby YearBook Inc

Navid, 2009. The Incidence of Back Pain, http://www.zimmerspine.eu/global/ action, akses tanggal 30 Maret 2011.

Wang Runsheng dan Ward Michael M. 2015. Arthritis of The Spine. Spinal Imaging and Image Analysis. Switzerland. Springer International Publishing. 
Lampiran Hasil Penelitian

Tabel 1.

Karakteristik dasar subjek penelitian

\begin{tabular}{lcccc}
\hline \multicolumn{1}{c}{ Karakteristik } & \multicolumn{2}{c}{ Kelompok Perlakuan I } & \multicolumn{2}{c}{ Kelompok Perlakuan II } \\
\cline { 2 - 5 } \multicolumn{1}{c}{ Subjek penelitian } & $\mathrm{n}$ & $\%$ & $\mathrm{n}$ & $\%$ \\
\hline Kelompok usia: & 2 & 20 & 2 & 20 \\
$35-40$ tahun & 2 & 20 & 3 & 30 \\
$41-45$ tahun & 2 & 20 & 2 & 20 \\
$46-50$ tahun & 4 & 40 & 3 & 30 \\
$\geq 51$ tahun & & & & \\
& 5 & 50 & 5 & 50 \\
\hline Jenis kelamin : & 5 & 50 & 5 & 50 \\
Laki-laki & 5 & & & \\
Perempuan & 5
\end{tabular}

Tabel 2.

Nilai fleksibilitas lumbal sebelum dan sesudah pemberian Ischemic compression technique (ICT) dan Myofascial Release Technique (MRT)

\begin{tabular}{lccc}
\hline Kondisi & Nilai Rerata & Standar Deviasi & $\mathrm{n}$ \\
\hline Kelompok perlakuan ICT & 16,450 & 0,5503 & \\
Pre test & 17,700 & 0,5375 & \\
Post test & 1,250 & 0,3536 & \multirow{2}{*}{10} \\
Selisih & & & \\
\cline { 1 - 3 } Kelompok Perlakuan MRT & 16,650 & 1,2921 & \\
Pre test & 18,600 & 1,2649 & \\
Post test & 1,950 & 0,7619 & \\
Selisih & & \\
\hline
\end{tabular}

Tabel 3.

Hasil Analisis Uji Wilcoxon pada fleksibilitas lumbal kelompok perlakuan Ichemic Compression Technique (ICT)

\begin{tabular}{lccccc}
\hline \multicolumn{1}{c}{ Kondisi } & $\mathrm{n}$ & Nilai Rerata & SD & $\begin{array}{r}\text { Beda } \\
\text { Rerata }\end{array}$ & $\mathrm{p}$ \\
\hline Fleksibilitas : & & & & & \\
Pre test & 10 & 17,70 & 1,06 & 4,02 & 0,005 \\
Post test & 10 & 21,72 & 0,97 & & \\
\hline
\end{tabular}


Tabel 4.

Hasil Analisis Uji Wilcoxon pada komponen Fleksibilitas lumbal kelompok perlakuan Myofascial Release Technique (MRT)

\begin{tabular}{lcccccc}
\hline \multicolumn{1}{c}{ Kondisi } & $\mathrm{n}$ & $\begin{array}{c}\text { Nilai } \\
\text { Rerata }\end{array}$ & SD & $\begin{array}{c}\text { Beda } \\
\text { Rerata }\end{array}$ & $\mathrm{Z}$ & $\mathrm{p}$ \\
\hline $\begin{array}{l}\text { Fleksibilitas : } \\
\text { Pre test }\end{array}$ & 10 & 17,67 & 0,84 & 2,91 & $-2,805$ & 0,005 \\
Post test & 10 & 20,58 & 1,09 & & & \\
\hline
\end{tabular}

Tabel 5.

Hasil Analisis Uji Mann-Whitney pada komponenFleksibilitas Lumbal antara kelompok perlakuan ICT dan kelompok perlakuan MRT

\begin{tabular}{l|c|c|c|c}
\hline \multicolumn{1}{c|}{ Kelompok Responden } & $\mathrm{n}$ & $\begin{array}{l}\text { Rerata } \\
\text { Selisih }\end{array}$ & $\mathrm{S} \mathrm{D}$ & $\mathrm{p}$ \\
\hline Fleksibilitas : & 10 & 1,250 & 0,3536 & 0,035 \\
Kelompok Perlakuan ICT & 10 & 1,950 & 0,7619 & \\
Kelompok Perlakuan MRT & 10 & & \\
\hline
\end{tabular}

